\title{
ULUSAL GRUP HAKLARI VE BU KONUDA MEYDANA GELEN GELIŞMELER
}

\author{
Prof. Dr. Ayge Füsun ARSAVA*
}

DH'na gorre prensip olarak sadèce egemen devletler hak ve yuikümlülüklere sahiptir. Bireyler bu hukuk düzeni çerçevesinde doğnudan karşımıza çıkmaz. DH çerçevesinde birey en fazlasından dolaylı olarak DH tarafından lehine düzenleme yapılan birim olarak ortaya çıkar. Aynı sonuç gruplar bakımından da geçerlidir. Klasik DH'nun temel struktüri dikkate alındığında, bireylerin ve grupların $\mathrm{DH}$ düzeninde himayesinin çok zor olduğu aşikârdır (Otto Kimminich, "Der Internationale Schutz der Einzelnen", AVR, Bd. 15 (1972), s. 402 vd.).

Azınlıkların ve ulusal grupların haklarının uluslararası seviyede korunması sorunu işte bu noktada ortaya çıkmaktadır. Ancak zamanımızda deģişik gelişmeleri müşahade etmek mümkündür. Egemen devletlerin uluslararası hukuk düzeninde temel direk teşkil ettiği klasik DH dơnemi, yüzyılımızda sona ermiştir. DH düzeninde meydana gelen gelişme sonucu, egemen devletlerin savaş hakkı (ius ad bellum) ortadan kalkmış, bunun yerine BM anlaşmasının 2. madde 4. fıkrasında dile geldigi gibi devletlerin barışı konuma mükellefiyeti ortaya çıkmıştur. Bu sonuç, devletlerin egemenliğinin uluslararası hukuk düzeninde hiyerarşisini kaybetmesinden dogmaktadır.

Bu duruma, devletlerin dünya siyaset sahnesinin tek aktơrü olmadıkları gerçeği de eklenmektedir. Ancak buna ragmen egemen devletler, uluslararası hukuk düzenindeki hakim pozisyonlarını muhafaza etmekte ve uluslararası hukuk düzeninin temel elementi olma niteliğini yakın gelecekte de korumaya kararlı gözükmektedir.

DH'nun bu gelişim sürecinde birey ve grup haklarının geliştirilmesini ve korunmasını şaşılacak bir süratle kabul ettiği görülmektedir. Grup haklannın himayesi hatta birey haklarının himayesine nazaran daha ơnce ele alınmışur. Bu çalışmalar MC (Milletler Cemiyeti) döneminde başlamıştır. MC azınlıkların himayesi sisteminin başarısızlığa uğramasının nedenleri çeşitlidir. Ancak temel sebep, DH düzeninin struktüri itibariyle azınlıkların hak sahibi deģil, yararlanan statüsünde mütalaa edilmesidir. MC'nin azınlık himayesi, anlaşmalara taraf devletlere (çok uluslu devletlere ve garantơr devletlere)

\footnotetext{
* Ankara Oniversitesi, Siyasal Bilgiler Fakültesi Ögretim Uyesi
} 
haklar ve yükümlülükler getiren bir sistem gelişı̇rmişti (Herbert Kraus, "Das Recht der Minderheiten", 1927, s. 50\%d.).

Azmlık, tanimı ilibariyle bir etnik grup ol גşturması ve kendi devleti olmaması nedeniyle, DH normlanının icrası için gerekli orgasılara sahip deģildir. Geçerli uluslararası düzen çerçevesinde azınlığ a etkin bir himaye sadıce IH ve ulusal hukuk kombinasyonu ile saģlanabilir. DH dü:zenlemesi ulusal hukuku desteklemektedir; ulusal düzenleme DH normunu icra etmekted.r. Azınlıkların himayesi. pızitif hukukun takibinden daha fazlasını icap ettirmektedir. Bu çerçevede işaret edilmesi gırekli yakın zamandan bir ơrnek bulunmaktadir. Isviçre de ralışma grubunca (Arbeitisgruppe) Federal Anayasanın total revizyonuna hazırlık çalışmalan çerçevesinde ya,ılan kamu oyu araştırmasında, azınlık hukukuna yeni anayasada yer verilip verilmemisi sorulmuştur. Zürih Kantonu'nun bu soruya verdił̧i cevap, bir azınlığın devlet içinde: kendisini iyi hissetmesi için anayasa garantisi kadar, anaya:ia tarafından düzenlenemeyen., ulusal gruplar arasında eğitim ve enformasyon değiş tok:uşu ile yaratılan psikolojik atmosferin gerekli olduğunu ortaya koymuştur (Arbeits ’ruppe für die Vorbereitung einer Total revision der Bundesverfassung, Aritworten Bd. I Kantone, Eirn 1969/70, s. 70). Kanton Appenzell cevabını daha açık bir şekilde formüle etmiştır : "A.2ınlıkların himayesi için düşünülen tüm Repertoire, çogunnukta bu konuda gerçek bir anlay'ş olmadığı takdirde işe yaramaz. Azınlıkların çıkarları bakımından en büyük g̣aranıi Isviçre'de geçerli vatandaşlık kültürüdür" (lbid, s. 689).

Isviçre kantonları bu şekilde MC azınlık hiınaye sisteminin çökmesine neden olan sebebi açık bir şekildı dile getimniştir. Devlıtlııin $\mathrm{DH}$ seviyesinde óngörülen azınlık sisteminin gereklerini yerine getirmemesinde salyısız sebepler bulunmaktadır. Azınlık sorunlannın ve ülkesel sorunlann birbirine kan,tıg, MC dönemi bunu göstermektedir. Ikinci dünya savaşından sonra DH literatüründe mütecanis olarak, DH seviyesinde azınlık himayesinin bir geler:eł̆i olmadığı gơrüşü ten:sil edilmiştir. Ancak problem hiçbir şekilde unutulmamıs, hatta BM organlannda, ס:ellikle Ekonomik ve Sosyal Konseyde görüşülmüştür. 7.4.19.50'de BM Genel Sekreteri MC döneminde azınlıklann himayesine iliş̧in bir rapor yayın.amışır. Bu çalışma şinıdiye kadar geçerli azınlık anlaşmalanının, onlar tarafından himaye edilen azınlıkların buntan böyle mevcut olmaması nedeniyle geçersiz olduğunu vurgulayan dikkat çeken bir :onuca ulaşmışır (Karl Doehring, "Das Gutachten des Generalsekreters der VN über dis. Fortsetzung der nach dem ersten - Weltkrieg eingegangenen Minderheitenschıtzverpflichtungen", Zeitschrift für auslaendisches offentliches Recht und Volkerrect.t. Bd. 15(1953/54) s. 541 vd.).

Hazırlanan çalışrna buna karşılık ulusal azınlıklarnn nasıl ortadan kalkuğı konusuna kesinlikle değinmem:ktedir. Rapor sonuç olara.k bir iddia daha ortaya atmakta, insan haklanının korunmasına ilişkin çalışmalann azınlıkıarın korunmasına da hizmet edeceğini ve bu nedenle uluslararası bir azınlık hukukunun fuzuli olacağını belirtmektedir.

Bireysel insan haklanının ulusal grup haklarının himayesi için kullanılması hiçbir şekilde yanlıs de gildir. Zira ulusal grup haklannın en onemli dayanaklarından biri, kendileri bakımından herhangi bir zarar dogmaksızın münferit bireylerin kendilerini belli bir gruba mensup olarak açıklama hakkıdır (Peter Pernthaler, "Der Schutz der ethnischen Gemeinschaften durch individuelle Rechte," 1964). Ancak bireysel hakların spesifik ulusal grup haklarını himaye etmeye yetmeyece jłi de açıktır. Bu nedenle aşagłı yukarı 10 yıldan beri DH literatüründe ulusal grup ve ulusal grup haklarına yeniden dónüs 
gozlenmektedir (Theodor Veiter, "Nationalitaetenkonflikt und Volksgruppenrecht im ausgehenden 20. Jahrhundert," 2. Bd., 1984).

Ulusal grup haklanı için günümüzde DH çerçevesinde oncelikle halklann SDR (Selfdeterminationsright) hukuki bir dayanak teşkil etmektedir. DH literatüründe hala kısmen temsil edilen, SDR'ın halklara tanındığı buna karşılık ulusal gruplara tanınmadığı yolundaki gorrüs, yavaş yavaş ağırlığını kaybetmektedir. Bu başan, içlerinde Fritz Münch ve Theodor Veiter'in de bulunduğu küçük bir grup DH' çusunun çalışmalanyla sağlanmış ve bu şekilde BM anlaşmalarında ve Genel Kurulun sayısız kararlarında yer alan SDR ile bağlanulı olarak kullanılan "people" søzünün dar yorumu terkedilmiş ve halklanın SDR'ın ulusal gruplara da tanındığ kabul edilmiştir.

Ancak SDR'ın ulusal gruplar bakımından kabulü kendiliginden bir ulusal grup hukukunu tesisi etmemekte, sadece uluslararası bir ulusal grup hukukunun tesisi için yapılan çalışmalara bir dayanak oluşurmaktadır. SDR ulusal gruplann sahip olabileceği tek hak deģildir. SDR oncelikle bir ulusal grubun yaşadığı bolgenin başka bir devlete bırakılmasının sőz konusu olduğu durumlarda etkisini gőstermektedir. Oysa varlığını korumak isteyen bir ulusal gruba ilgili devletin yasama, yürütme ve yargı organlan tarafından dikkate alınması ve gerçekleştirilmesi gereken sürekli hakların temin edilmesi gereklidir.

Işte bu noktada, uluslararası bir ulusal grup haklarnnın oluşturulması için yapılan çalışmalar, DH'nun temel struktüründe yatan bir zorlukla, diģer bir ifade ile ulusal gruplara DH sujeliği tanınması sorunu ile karşılaşmaktadır. Bu onemli bir problem olmakla beraber, çơzümlenmesi imkansız deģildir. Diğer bir ifade ile bir uluslararası ulusal grup haklannın oluşturulması için yapılması gereken iş, ulusal gruplann şu anda deģişim içinde bulunan DH düzeni ile uyum içinde $\mathrm{DH}$ hak ve mükellefiyetleri ile donaulmasidir.

Bu deģişim MC'nin azınlık haklan sisteminden ulusal grup haklan sistemine geçis ile saglanabilir (Theodor Veiter, "Natiolitaetenkonflikt und Volksgruppenrecht im 20. Jahrhunder," I. Bd., 2. Aufl. 1984, s. 208 vd.).

Ancak şu anda gelişmelerin en başında bulunmaktayız. BM seviyesinde hala azınlıkların himayesine ilişkin bildiri metni tartışılmaktadır (insan hakları komisyonundan bir grup 1978'de bu metnin hażırlanması ile gorevlendirilmiştir. Bknz.: UN- Kommission on Human Rights, Resolution 21 (XXXV), Un-Document E/CN. 4/1437 (1979).

16.12.1966 tarihli uluslararası medeni ve siyasi haklar sozleşmesinin 27. maddesi de açıkça azınlıklardan sőz etmektedir. Bu madde metninde, ülkelerinde etnik, din yahut dil azınlığ olan devletlerin, azınlık mensuplarını, grubun mensuplanyla birlikte kendi kültürel yaşamlanna sahip olma, kendi dinlerini açıllama ve icra etme, dillerini kullanma hakkından mahrum edemiyecekleri" ifade edilmiştir. Burada sơz konusu olan düzenleme bireyler üzerine inşa edildił̧i için, literatürde hatta bu hükmün azınlığa doğrudan yarar saģlayan bir hüküm olmadığı, azınlıklann himayesine ilişkin bir hüküm olmadığı görüş̧ü ileri' sürülmüş̧ür. Ancak Fritz Münch, ulusal grubun ozel durumunun sơz konusu hükmün içerił̧ini teşkil etmesi nedeniyle 27. maddeyi ulusal grup haklanna ilişkin bir düzenleme olarak kabul etmiştir (Fritz Münch, "Volksgruppengrecht und 
Menschenrechte, in : System eines internationaLın Volksgruppenrechts," 1. Teil, bearb. von Theodor Veiter, 1970, (s. 102).

AGIK'da 1.8.1975'de Helsinki'de kabul etlilen nihai senet de benzer bir ikilem içindedir. Senet'in ilgili búlümünde taraf devlıttler, ulusal azınlıklann veya bőlgesel kültürlerin kendi aralarında, kültürün çeşitli alanlannda yaptıkları katkıyı kabul ettiklerini, ülkelerinde ulusal azınluklann ve b8: rgesel kültürlerin bulunması durumunda bu katkıyı mensuplanının ıneşrı çıkarlarını dik.kate alarak kolaylaştıracaklarını ifade etmektedir.

Bőyle bir ifade DH seviyesinde herhangi bir geliģme temin edemez. Bu düzenleme MC'nin başarısızlığa uğramış azınlık himayesint:, geçerli DH'na istinaden tesis edilecek ulusal grup haklarına nazaran çok. daha yakın göziikmektedir.

Aynı saptama 15. Ocak 1989 tarihli Viyana AGIK toplantısının nihai metninde geçerli kalmıştr. Bu metnin 18. maddesi :

"Taraf devletler sürekli olarak nihai senedin ve Madrit toplantısının nihai dökümanının ulusal azınlıkların himayesine ilişkin hükümlerini yerine getirmeye çalışacaktır.

Taraf devletler ülkelerinde bulunan ulusal azınlık mensuplarına insan haklarını ve temel ozgürlükleri temin için bütün gerel:li kanuni, idari, adli ve diğer ónlemleri alacaktır ve aynı şekilde bağlı olduloları ilgili uluslararası dokümanları uygulayacaklardir.

Taraf devletler bu insanlan diskrimine ettmekten kaçınacaktır ve onlann insan haklan ve temel ơzgürlükler alanındaki mişrı çıkar ve gayretlerinin gerçekleşmesi için çalışacakur"

hükmünü içermektedir.

Prensip niteliğindeki bu açıklamalar Avrụ̣ada güvenlik sorunlan başlığını taşıyan 19. maddede daha somut bir şekilde ifade edilmektedir. Bu düzenlemeye göre "taraf devletler ülkelerinde buluran ulusal azınlıklantı etnik, kültürel, dil ve dini kimliklerini koruyacakur ve bu kimligin korunması için imkanılar yaratacaktır. Azınlık mensuplan tarafindan haklann serbest olarak kullanılmasına saygı gősterecek ve onlann digerleri ile tam olarak eşitligini temin edecektir".

Bütün bu yapılanların çok olumlu gelişnzeler olmakla beraber, DH seviyesinde etnik bir uluslararası grup hakları beklentisi mıvacehesinde yeterli olduğunu sóylemek mümkün deģildir. Azınlıkların himayesi azınlık mensuplarının digerleri ile tam olarak eşit kılınmasından daha fazlasını gerektirmektedir. Aynı durum geleneksel azınlık himayesini kapsayan, ancak onu oluşmakta olan DH düzeninde uygun yeni bir yere yerleştiren, ulusal grup hakları için de geçerlidir.

Azınlık haklarından ulusal grup haklarına doğru ortaya çıkan gelişme Avrupa Konseyi çerçevesinde de henüz tamamlanmamıştır.Avrupa Insan Hakları Konvansiyonunda yasaklanan diskriminasyon sebepleri arasında ulusal bir azınlıga 
mensup olmanın da sayıldığı, azınlık himayesine ilişkin bir hüküm olarak nitelendirilen, 14. madde dışında bu konuda bir hüküm bulunmamaktadır.

Tüm dünyada azınlıkların himayesi için yapılan onemli işlerin titizlikle kayıt edildiği ünlü Capotorti raporunda, Avrupa Konseyinin çalışmalanna raporun kendisi 15000 satırdan oluşmakla beraber sadece 17. satır aynimıştır (Study on the Rights of Persons Belonging to Ethnic, Religious and Linguistic Minorities, 1979, UN-Document $\mathrm{CE} / \mathrm{CN}$. 4/Sub. 2/384/Rev. 1, s. 30). Bu 17 satır içerisinde Avrupa Insan Haklan Konvansiyonunun 14. maddesine yapılan bir atif ve Avrupa Konseyi thtisas Komitesinin (Experten komitee) Avrupa Insan Haklan Konvansiyonuna azınlıkların himayesi için ek bir protokol yapılmasına gerek görmediği hakkında yapuğı olumsuz saptama yer almaktadır. Bu saptama 1973 'te yapılmıs ve 1976 'da tekrar edilmiştir. Ancak diğer uzmanlar şüphesiz bu görüşü paylaşmamaktadır. Ermacora Avrupa bolgesel sistemindeki bir boşluktan sőz etmektedir. Ermacora hiç çekinmeden görüşlerini şoyle açıklıyor : "Avrupa Konseyindeki devlet temsilcileri ulusal grup ve Azınlıkların himayesini, dokunulmaması gereken bir konu olarak gormektedir. Sadece siyasi durumun ciddi ve azınlıkların varlıklannın gerçek bir problem olduğu durumlarda, konu uluslararası seviyede tarışılmaktadır. Ne yazık ki sadece kuvvet kullanıldığı durumlarda kamu oyu ve basın konu ile ilgilenmekte, diplomat ve politikacılar konuya egrilmektedir (Felix Ermacora, Der Minderheiten- und Volksgruppenschutz vor dem Europarat, in : System eines internationalen Volksgruppenrechts, bearb. von Theodor Veiter, Bd. 3, II Teil 1972, s. 75).

Avrupa Konseyini ancak bu konuda çalışmaya iten girişimlerin eksik olduğunu söylemek mümkün değildir. Daha 1949 yılında, Avrupa Konseyinin kurulmasından kısa bir süre sonra, azınlik sorunu hukuk komisyonunun Avrupa Insan Hakları Konvansiyonuna ilişkin ilk tasarı hakkında verdiği raporda zikredilmiştir. Raporda Komisyon tarafından alınan karar ışığında, ozgürlük hakları için ơngorulen garanti sisteminin, ulusal azınlığa mensubiyet nedeniyle diskriminasyona uğramayı engellemesi gerektigi vurgulanmışur (Dokument 77 der Beratenden Versammlung vom 5. September 1949). Rapor ayrica komisyonda, ulusal azınlık haklarının daha kapsamlı himayesi sorununun tartışıldığını ve bu sorunun oneminin oybirliği ile kabul edildiğini belirtmektedir. Sonuç olarak rapor, ulusal azınlıkların tam olarak tanımlanması sorununa bakanlar komitesinin dikkatini çekmiş ve sorunun daha sonra yeniden incelenmesi gerekliligini ortaya koymuştur.

Avrupa Konseyi danışma meclisi 1950-1954 yılları arasında Bakanlar Komitesine bir çok kez bu çerçevede talepte bulunmuştur. Ancak Bakanlar Komitesi her seferinde Avrupa Insan Hakları Konvansiyonunun 14. maddesine işaret ederek bu talebi reddetmiştir. Isveçli parlamenter Dickson'un azınlık sorunlarına ilişkin sürekli bir alt komisyon kurulmasına ilişkin talebi de danışma meclisinde çoģunluk bulmamakla (Dokument 508 der Beratenden Versammlung vom 20. April 1956) beraber hukuk komisyonunda, 29 Ekim 1957 tarihli 136 nolu karann (Der Text der Entschliessung 136 vom 29 Oktober 1957 ist abgedruckt in Europa Archiv 1957, s. 10516 f) alınmasına neden olan bir raporun hazırlanmasina (Dokument 731 der Beratenden Versammlung von 22 Oktober 1957) esas olmuştur.

Bu kararda azınlıkların himayesi için Avrupa Insan Haklan Komisyonunun 14. maddesinin yeterli olduguna ilişkin eski görüş tekrar edilmiş̧̧ir. Bununla beraber karar bir adım daha aumıs ve bu alanda ne olçüde ilerleme kaydedildiģini saptamak amacıyla geçerli 
kanuni ve idari dủzenlemeleri karşılaştıran bir çalı̧̧ınanın yapılmasını istemiştir. Bu istek Bakanlar Komitesi tarafından, Danışma Meclisinir üyelerinin gerekli belgeleri ancak üye devletlerin parlamentolarının yardımı ile saglayabılecekleri gerekçesi ile reddedilmiştir. Bunun dışında bu konunun açık olarak tartışılmasının ciddi sorunlara yol açabileceģi ve bunun da yarardan çok zarar getirebileceği belirtilmiştir (Peter Leuprecht, "Der Europarat und das Recht der nationalen Minderheiten", Bknz. : Beitraege zu Fragen der Minderheitenschutzes und des Minderheitenrechts, Heft Nr. 2 der Schriftenreihe der Arbeitsgemeinschaft für Menschenrechte und Völk:rrrecht des internationalen KonstantinOrdens, 1967, s. 18).

Buna rağmen hukuk komisyonu ulusal azınlıklar hakkında yeni bir rapor hazırlamış ve 30.4.1959'da arzetmiştir (Bernhard Schloh, Fin Bericht des Europarates über die nationalen Minderheiten, Jahrbuch für Internationales Recht, 9. Bd., 1960, s. 77 vd.). Rapor bununla beraber Avusturya'daki Çek Sloven ve Hırvat azınlığı, Pommer'deki Alman azınlığ, Federal Almanya'daki Danimarka azınlığı, Italya'daki Yugoslav azınlığı ile ve Güney Tirol sorunu ile sınırlı kalmıştır. Fiaporda sonuç olarak Avrupa Konseyi çerçevesinde Avrupa insan Hakları Konvan:iyonunun 14. maddesinin Azınlık mensuplanın yeterince koruması gerekçesine istinaden, MC orneğine göre bir azınlık himaye sisteminin yaratılmasının gerekli olmadığ görüşü vurgulanmış ve aynca Avrupa Konseyine üye olan devletlerin ülkelerinde azınliklarn durumlannın memnuniyet verici oldugu ifade edilmiştir.

Bu görüşü Danışma Meclisi 17 Eylül 19:j9 tarihli 213 nolu tavsiye kararında benimsemiştir. Bununla beraber tavsiye karannda Bakanlar Komitesine, aralarında ulusal azınlıklar nedeniyle uyuşmazlık olan veya uyuşmazlık çıkabilecek üye devlet hükümetlerinden hukukun üstünlügüi ilkesine istirıaden önce bilateral görüşmelerle ve bu görüşmelerin fayda etmemesi durumunda, Avrıpa Konvansiyonunun uyuşmazlıkların barışcı yollarla çőzümlenmessi için óngçrdügü yöntemin uy.gulanması ile uyuşmazlıklarına çơzüm aramalarını istemesi tavsiye ediìmiştir.

Bu tavsiyeye uyulmamıştır. 2 Subat 1961 tşrihinde azınlık sorunu Lannung-raporu ile yeniden Avrupa Konseyinin gündemine gelniştir (Dokument 1299 der Beratenden Versammlung vom 26.4:1961). Söz konısu rapor Avrupa Insan .Hakları Konvansiyonuna ek 2 nolu protokola azınlıkları himayesine ilişkin bir düzenlemenin alınmasını onermiştir. Bu düzerıleme daha sonra uluslararası medeni ve siyasi haklar sőzleşmesinin 27. maddesinde karşımıza çıkan benzır bir şekilde formüle edilmiştir. Avrupa Konseyi danışma meclisi raporda öngörülen örieriyi 26.4.1961 tarihli bildirisinde kabul etmiştir (Dokument 285 (1.961) der Berálenden Versammlung vom 26.4.1961). Ancak Bakanlar Komitesi rapora e.gilmemiştir.

1976'da Danışma Meclisi konuyla yeniden ilgilenmeye başlamıştur. Sieglerschmidtraporu BM insan hakları sőzleşmesine ilişkin tartışmalar ile bağlantılı olarak bu sőzleşmelerin özüne ilişkin düzenlemelerin üstlı!nilmesini tavsiye etmiş ve bu meyanda uluslararası medeni ve siyasi haklar sözleşmesinin 27. maddesini zikretmiştir (Dokument 3352 der Beratenden Versammlung vom 15.9.1976). Ancak Avrupa Insan Hakları Sözleşmesi'nin bir ek protokol veya diğer bir önlemle uygun bir şekilde genişletilmesi şimdiye kadar gerçekleşmemiştir (Europarat, Strassburg 20 bis 22 Oktober 1987, Bericht über regionale oder Minderheitengruppen in Eur:spa, s. 145 vd.; Europarat, Strassburg 15 bis 18 Maerz 1988, Entschliessung 192 (1988) ülser regionale und Minderheitensprachen in Europa, 154....). 
Avrupa Parlamentosunun ortaya çıkışıyla beraber bir Avrupa ulusal grup hukukunun yaratılması çalışmalanı tarihinde yeni bir dơnem başlamıştır. Parlamenter Alfons Goppel ulusal grup ve azınlık haklanına ilişkin bir rapor tasansı hazırlamıştır. Bu rapor tasarısın 31 Temmuz 1984 'de 42 Parlamenter tarafından verilen karar dileksesi takip etmiştir (Entschliessungantrag, Text in Europa Ethnica 1984, s. 233 vd). Uluslararası medeni ve siyasi haklar sozzleşmesinin 27. maddesi, AGIK Helsinki nihai senedi ve diğer ilgili uluslararası enstrümanlar ı̧̧ı̆̆ında parlamenterler belli prensiplere göre bir Avrupa ulusal grup hukukunun tesisini talep etmişlerdir. llk planda her ulusal ve etnik grubun, hem Avrupa topluluklarında hem de her Avrupa Topluluklar ülkesinde kültürel, sosyal ve siyasi haklarının korunması hakkı vurgulanmışur. Bunu iki diğer temel prensip takip etmektedir :

1. Her ulusal grup kendi ana dilini ठzel ve toplum hayatunda yahut ekonomik ilişkilerinde umum içinde, idari merciler ve mahkeme onünde sınırsız olarak kullanma hakkına sahiptir.

2. Ulusal gruplann ve onlann mensuplannın sürgün, assimilasyon veya ulusal gruplann yok edilmesi şeklinde diskriminasyonu yasak oldugu gibi, bir ulusal grubun meskun bulunduğu bir bölgenin sun'i bir şekilde demografik yapısının değiştirilmesi de yasaktur.

Bu çerçevede 42 parlamenter ongơrülen Avrupa Birlił̧i için bir Avrupa Ulusal Grup charta (şartı) nın oluşturulmasını talep etmişlerdir. Ancak 14.2.1984'de Avrupa Birligi'nin teşkiline dair Avrupa Parlamentosu tarafından kabul edilen anlaşma tasarısında ulusal grup haklan konusuna yer verilmemiştir.

Bir Avrupa ulusal grup hukukunun oluşturulması, devleti mutlak egemenlikten sınırh egemenliğe götüren DH'nun genel eł̧ilimine uygun düşmektedir (Eberhard Menzel, "Das Völkerrecht und die politisch-sozialen Grundstrukturen der modemen Welt", bknz.: Frieden und Volkerrecht, hrsg. von Georg Picht und Constanze Eisenbart, Stuttgart 1973, s. 413).

Parlamenterlerin karar tasarısı medeni ve siyasi haklar Komisyonuna havale edilmiştir. Komisyon parlamenter Graf Stauffenberg'i raportơr olarak tayin etmiştir. Raportör 17 Mart 1988'de Avrupa Topluluklarina üye olan devletlerde ulusal grup haklan şarı başlığını taşıyan tasarısının 1. kısmını ve 5.5.1988'de de gerekçeyi arzetmiştir. Ancak rapor Komisyon tarafından iş hacmi nedeniyle 1989 yasama dơnemi içerisinde kabul edilememiştir (Avrupa Parlamentosunun 10.4.1989 tarihli açıklaması). Avrupa Parlamentosunun iç tüzügüune göre de rapor ve karar ónerileri yasama dőneminin bitmesi ile geçersiz olmaktadır. Rapor tasansında onerilen karann girişinde (praeambel) Avrupa Parlamentosunun ulusal gruplara varlıklarını ve kültürel kimliklerini garanti eden kapsamlı bir ulusal grup hukukunun oluşturulmasında ilerlemeler kaydetme iradesi yeniden teyit edilmektedir (Europaeisches Parlament, Dokument PE 121, 212, s. 6). Bu amaçla üye devletlerden çok taraflı bir anlaşma olarak bir ulusal grup şarının oluşıurulması talep edilmiştir. Tasan, gerekli tanımlann yanısıra bireylerin ve ulusal grupların kişisel haklarını saptayan ve devletlere muayyen yükümlullükler getiren 5 maddeden oluşmaktayd. 
Bu tür bir uluslararası ulusal grup haklarının j’aratılması günümüzde DH'nun genel tandansına uymaktadır. Avrupa Ulusal grup haklarının oluşturulması Avrupa geleneklerine de uymaktadir.

Ulusal grup haklarının, farklı etnik unsurların büyük uluslar içinde erimesini engellemesi nedeniyle, tabii olmadığını iddia edenler bir yanılgı içinde bulunmaktadır. Tarih ulusal devlet rüyasının tehlikeli bir illusion olduğunu kanıtlamışır. Avrupada ulusal devlet akımindan once yüzyıllar boyu çeşitli devletlerde etnik topluluklar yanyana yaşamışlardır. Toplumun etnik farklılıklar gősterınesi Roma Imparatorluğu için gayet normal bir durum olduğu gibi Kutsal Roma Imparatorlugu ve daha sonra mutlakiyet ve meşruti monarşi dönemlerinde karşımıza çıkan devletler bakımından da normaldi. Çeşitlilik, Avrupa'nın dikkate alınması gereken bir రzelligidir. bu sebeple Avrupa ulusal grup hukukunun oluşırulmaması durumunda, Avrupa Birligini tesis edecek eserde bir anlam eksikligi ortaya çıkacaktır. Avrupa serbest pazardan, ortak pazardan, ekonomik alan olmaktan, ekonomik gü̧̧lerin serbest olarak dolaştığı bir alan olmaktan ötedir. Avrupa, ulusların ve ulusal grupların yurdudur. Avrupa esasen ulusların ve ulusal gruplann tarihi etkileriyle oluşmuştur. Uluslar ves ulusal gruplar yok edilme tehlikesi içinde olan hayvan yahut bitki türleri deģildir. Onlanın Avrupa kıtasının gerçek enerji kaynağı olarak mütalaa edilmesi ve bu nedenle dt: yasşam haklarının münferit bireylerin haklariyla beraber korunması gerekmektedir.

\section{KISALTMALAR}

AVR : Archiv des Völkerrechts

DH : Devleder Hukuku

BM : Birleşmiş Milletler

AGIK : Avrupa Güvẹnlik ve Iş̧irliği Konleransı 